\title{
Reconstruction of Islamic Philosophy as a perspective for sustainable development of vocational education
}

\author{
Irina Sokolovskaya ${ }^{1, *}$, Rida Zekrist $^{2}$, Airat Shagapov ${ }^{2}$ \\ ${ }^{1}$ State University of Management, 109542, Ryazan ave., 99, Moscow, Russia \\ ${ }^{2}$ Bashkir State Pedagogical University named after M. Akmulla, 450000, st. October Revolution, 3a, \\ Ufa, Russia
}

\begin{abstract}
The idea of reconstruction of Islamic philosophy in modern conditions is actualized due to the fact that there are problems of a natural and social nature, which can be designated as catastrophes and crises. In such critical conditions of challenge, a synthesis of spirituality and scientificity is in demand, which is the foundation for solving emerging difficulties and consolidating humanity. In this regard, the authors of the article turn to the widely discussed controversy in modern Islamic discourse on the compatibility of Islam and science and come to the conclusion that it is inevitable to support and expand the possibilities of rational research and the search for knowledge inspired by the Qur'an. A classic historical example of the rationalization of knowledge in Islamic discourse is the Arabic-Greek philosophy - falsafa (al-falsafa al-'arabiyya al-mu'așira). The complex problems of the current level of development of religion, science, politics, economics, culture, and civilization require new research approaches, new dimensions and tools in the XXI century. The theory of self-organization and evolution of large nonlinear systems has become a new fact and factor in the development of the science of studying complex local and global problems.
\end{abstract}

\section{Introduction}

The starting point of our research was the article by Zoran Milošević [1] "Islam and Science", dedicated to the study of the compatibility of Islam and science, which shows that the contribution of Muslims to the development of world science is incredibly small, less than one percent, although every fifth inhabitant of the planet today is a Muslim ...

The debate about the compatibility of Islam and science began with Professor Ernest Renan (1823-1892) of the College de France in a lecture entitled "Islam and Science", which he gave on March 29, 1883 at the Sorbonne. Renan then expressed the opinion that positivist science and the spirit of Islam are incompatible. In response, Jemuladin el-Afghan, the father of Muslim reformism, asserted that the scientific lagging behind of Islam has nothing to do with its fundamental principles, but became its historical consequence [2, p. 75].

\footnotetext{
* Corresponding author: iren3d@yandex.ru
} 
Since then, the controversy has not subsided...

One thing is clear: Western and Eastern Europe are dubious about the question of the attitude of Islam to science. However, in terms of philosophical theology, the main purpose of early religious education ( 7 th to 11 th centuries) in Islam was to encourage conversion and develop a sense of common Muslim identity among students. According to the Prophet Muhammad, each verse in the Qur'an represents the word of God revealed to him for more than two decades, beginning in $610 \mathrm{AD}$. Each of them can be interpreted in seven different ways, which made it possible to diversify the meaning and application. The lives of these early Muslims and their training were not exclusively focused on Islam. On the contrary, even those seeking Islamic knowledge eventually switched their interests to business and family, while only the most intellectually oriented continued to expand their religious knowledge or their search for knowledge in astronomy, medicine, and other sciences.

AmraSabic-El-Rayess [3] writes that Brentjes agrees that elites saw scientific progress as the key to their prestige and, more broadly, to social development, while Bulliet believed that only about $4 \%$ of the urban elite were deeply involved in religious teachings. Islamic scholars such as Al-Jahiz (776-868) argued that the teacher should exemplify knowledge and focus on critical thinking in mathematics and writing as essential foundations of human progress, to which religious studies were secondary. Knowledge is one of the most frequently used terms in the Qur'an, and the Prophet Muhammad directly instructed Muslims to seek knowledge, even if it meant a trip to China.

In the Middle Ages, as we know, the perception of the ancient philosophical heritage (Aristotelianism, Neoplatonism) contributed to the development of rationalistic tendencies in Muslim theology (Mutazilites, Asharites).

In the general outline of the controversy, it is necessary to take into account Davydov's opinion, according to which, Arab-Islamic science is, to a greater or lesser extent, a collection of borrowed knowledge. Davydov [4] emphasizes that Indian numbers were borrowed from Armenians and Hindus, and "Arab philosophy" is the result of intercultural dialogue and the price that the peoples conquered by Muslims had to pay.

Agrees with Davydov and Maksat at Tarazi [5], who warns enthusiastic defenders of Islamic scholarship against being overly enthusiastic in describing the great scientific discoveries of Muslims who lived during the "Golden Age".

Comparing Islam and science, Sadovic M. [6, p. 8] believes that "the Qur'an declares truths and does not prove them, and science is forced, first, to establish the subject, which is being spoken about, and then to prove what it claims about it, which should be verified and experimentally. The Qur'an refers to the power of God, which is infinite and as such can be proved not in human experience, but in a miracle and in the unity of the fate of the world and humanity."

Today, secular Muslims also enter the world Muslim community, as those who accept an exclusively ultra-conservative and puritanical interpretation of Islam. Each community contextually interprets the ideas of knowledge and education as it sees fit. However, some overarching ideas have emerged throughout history and are currently influencing global radicalism in Islam.

Thus, despite the controversial controversy of Islamic discourse, most researchers believe that the early expansion of Islam was accompanied not by a rejection or neglect of science, but by its widespread support and an open call for rational research and the search for knowledge, inspired by the Qur'an. However, after the destabilization of the social world of Islam, the sense of belonging and reflection became internal and less reflective than that of the early Muslims. Faith began to prevail over the mechanisms of rationality that previously shaped Islamic aspirations. Such shifts in what was considered valuable in education played a significant role in the emergence of the phenomenon of radicalization of Islam. According to Amra Sabic-El-Rayess [7], education and knowledge are not the only or omnipotent forces 
shaping the trajectory of radicalization in Islam. It should be explored how and why Muslim communities, their leaders, educators and educational institutions have gradually changed their interpretation of education and knowledge.

In order to counter this trend, for the Muslim world to progress, it is necessary to revive and reclaim its passion for knowledge, which was demonstrated by the early Islamic Empire in its search for all known forms of knowledge that led to the Golden Age of Islam.

In his works - "Diniveijtimagymesieller" ("Religious and social problems") 1914; "Javami Kalim Sharkhi" ("Commentaries on the Hadith Collections") 1916 - Riza Fakhretdin considered the problems of reforming the Muslim world, defended the compatibility of Islam and science, called for a return to the original "pure" Islam.

According to Rail Fakhrutdinov [8], Fakhretdin, Barudi and Bigi were looking for ways to develop religion in new conditions, introducing a new, rationalizing principle into the religious worldview of the Tatar people.

The idea of reconstructing Islamic science, and above all, philosophy, in modern conditions is also being actualized due to the fact that problems of a natural and social nature arise, which can be designated as catastrophes and crises. In such critical conditions of challenge, a scientific approach is in demand, it is the foundation for solving emerging difficulties and consolidating humanity.

\section{Materials and methods}

To show the need for the reconstruction of Islamic philosophy (science) in the context of modern Islamic discourse, the authors turn to nonlinear methods of the theory of selforganization, the theory of catastrophes as the most adequate for analyzing complex, dynamic, global problems of sustainable development of modern society. In methodologically, this study uses a qualitative approach of phenomenology.

\section{Results}

Before moving on to the productive part of the study, let us note those research works that directly influenced the disclosure of the meanings and content of this work.

Researchers Aminuddin Hassan, Asmawati Suhid [9] study Islamic philosophy in the aspect of education as a holistic environment that includes the comprehensive aspects of knowledge. According to holistic philosophy, man is considered part of nature. The concept of resilience, which includes aspects of emotion, spirituality, intuition and human imagination, is reflected in the Islamic philosophy of education. This philosophy emphasizes the concept that every aspect is simultaneously interconnected (interconnected reality). The variety of aspects includes the method of practical training so that students can think and solve each difficulty based on the Quran. Education in the aspect of Islamic education as an approach to the implementation of the Islamic philosophy of education among students is becoming an effective method, since it is able to create a balanced person in terms of his physical, emotional, spiritual, and intellectual development.

Therefore, it would be a brilliant attempt for Muslims to continue the study of the nature of higher human abilities through awakening and education in a truly Islamic educational process, which will make a real contribution to the revival of the world's best educational practices.

Research by Nawal A. Al Eid, Boshra A. Arnout [10] aims to build a broad conceptual theory by applying a grounded theory approach to the Islamic approach to crisis and disaster management, the strategies used to manage them, the stages of crisis management, the characteristics of a leader who manages crises, and the role assigned to overcome these 
crises, such as the outbreak of the COVID-19 pandemic. A qualitative analysis of the Noble Qur'an verses and the noble hadith of the Prophet draws the Qur'anic approach from the Book of God and the Sunnah of the Noble Prophet. Based on these findings, the study offers some important insights that fill a gap in the literature on the Islamic model of crisis management. Thus, these results can be useful to policymakers and decision makers in crisis management as well as the pandemic outbreak crisis, COVID-19 as a model, and also provides them with strategies that enable them to effectively manage these crises for their overcoming and eliminating dire consequences.

Suyadi, Zalik Nuryana, Niki Alma Febriana Fauzi [11] showed that the theological movement was in the form of a religious position, as a product of Muhamma diyah'sijtihad, aimed at solving modern problems, in which Muhammadiyah tried to reconstruct the classical Islamic jurisprudence of the rule of worship in order to adapt to an emergency ... The study analyzed the arguments and their relevance in mitigating the impact of COVID19 , the medical health movement and the reconstruction of the fiqh of worship during an emergency, in particular, and how to deal with disaster from a theological point of view in general.

Thus, an interest in developing spiritual intelligence helps people adopt a positive outlook and achieve inner peace, as it improves self-control motivation in addition to the high stress of modern life at school, at home and at work. Spiritual intelligence is considered the most important type of intelligence due to its ability to influence people and change cultures and societies.

Based on the above, we can say that spiritual intelligence is the center and source of guidance for the human mind, as it is the compass of life. Therefore, we must be aware of the importance of spiritual intelligence in today's world and not forget about the seven things that, according to Gandhi, will destroy us: wealth without work, pleasure without conscience, knowledge without personality, trade without ethics, knowledge without humanity, worship without victims and politics without principles.

As far as disaster research is concerned, it is still limited to natural or geological disasters such as earthquakes, tsunamis, eruptions and hurricanes, as are the trends in disaster research in Australia, India and Asia, including disasters, in terms of religion, in Indonesia.

Sonia Akter [12] provides empirical evidence for a link between social cohesion and climate change adaptation in coastal Bangladesh prone to tropical cyclones.

In the work of Iuchi K., Mutter J. [13], three recovery cases - the earthquake and tsunami in Tohoku (Japan), the storm surge in Leyte (Philippines), and the volcanic eruption in Yogyakarta (Indonesia) - are considered in order to study different government approaches to populationresettlement. In particular, it explores how the program design and governance structure affect the implementation and success of community resettlement, and how this affects community participation and resettlement outcomes in the long term.

An article by Rokib M. [14] is devoted to the experience of a religious volunteer group called Santana (Islamist student response to a natural disaster) in the East Java region. The group is part of an Islamic educational institution that emphasizes religious aspects and attempts to implement religious values in everyday life. The group attaches religious significance to disaster management experiences and efforts to help victims of natural disasters. This study reveals a large number of religious symbols referring to natural disasters as natural and theological phenomena.

Studies have emerged looking at unnatural or non-geological disasters such as social crises and ethnic conflicts like the 2017 Rohingya humanitarian disaster.

Thus, the reviewed works actualize various aspects of the universal problem - the reconstruction of Islamic science and philosophy in modern conditions, due to the fact that there are problems of a natural and social nature - catastrophes and crises that require a synthesis of spirituality and scientificity to resolve difficulties and consolidate humanity. 


\section{Discussion}

As the analysis of the discussion part of the work has shown, research is needed to mitigate the consequences of the catastrophe associated with COVID-19, from the point of view of Islam, which can counteract anti-scientific and anti-intellectualism.

According to the researchers Suyadi, Zalik Nuryana, Niki Alma Febriana Fauzi [15], Muhammadiyah, as one of the oldest and largest public-religious organizations in Indonesia, compiled the Fiqh of disasters, which later became the regulatory framework in mitigating the effects of Covid-19.

Muhammadiyah [16] responded to Covid-19 in three ways, namely medical, theological and educational aspects. In the medical field, Muhammadiyah provided medical services in the form of 74 Covid-19 emergency hospitals with medical staff and humanitarian volunteers. In the field of theology, Muhammadiy put together a guide to worship in the midst of Covid-19 so that worship at home does not become clusters of the spread of Covid19. In the field of education, Muhammadiyah develops Islamic teaching materials so that many people can cope with the situation.

There is a knowledge and research gap about Covid-19 itself, and those that have accumulated are mainly focused on vaccination, treatment, healing and immunity enhancement. There is little research done from a social and religious perspective. This knowledge gap concerns the socio-religious and educational implications that Covid-19 has created.

The Covid-19 pandemic has jeopardized three of the five pillars of Islam at once. Many countries have restricted freedom of meeting and assembly, leading to the closure of mosques - even for obligatory prayer. While it remains impossible to make a pilgrimage to Mecca Saudi Arabia has closed this holy place for Muslims to visit. Fasting in the month of Ramadan is under threat.

For 30 days, Muslim believers must deny themselves food and drink in the daytime - as the Prophet Muhammad himself once did. Due to the pandemic and the measures to combat it, fasting in Ramadan seems impossible. One of the reasons is that avoiding food and drink during the day can contribute to the spread of the coronavirus, because extreme conditions increase the risk of COVID-19.

Muslims should fast only if it does not pose a threat to their health - sick and elderly people, like pregnant women, may not adhere to appropriate restrictions. But this exception to the rule has become a new reality for all Muslims in Ramadan in 2020 and 2021.

Thus, future research on a philosophy of disaster that focuses on Covid-19 mitigation from an Islamic education perspective will fill this gap, which will have implications for a new Islamic discourse in exploring non-geological mitigation of natural disasters beyond traditional fiqh reasoning. which are likely to be repeated in the future.

The theory of catastrophes, along with other modern theories of dynamical systems, has already significantly changed the usual ideas about the stability and inertia of the world. Thanks to the theory of catastrophes, today we better understand our responsibility for possible violations of the harmony and balance of opposite natural forces, it allows us to delve deeper into the essence of things, phenomena and processes of the real world.

Crisis management depends on the savvy and effective decision-makers during these crises. History provides many examples when, at critical moments, the fate of peoples depended on the decision of one person, and if he managed to "catch the moment", to understand the need for this or that action, then a new time began, new perspectives opened, great ideas were embodied.

Since in certain situations - at points of catastrophe - even minor movements can affect the course of development, - considers A. Chulichkov [17], - it will be very useful to be able to determine whether the system is far from such a point. Formally, for this, it is necessary 
to study the dependence of the system on external parameters in mathematical models, but in practice there are often cases when the researcher does not even have vague ideas about which evolutionary equation describes the development of the system. Nevertheless, even in these situations, it is possible to indicate some indirect signs that the system under study is near the point of catastrophe.

Islamic discourses, which for a long time seemed to bethe fruit of scholastic speculations, in the light of the theory of self-organization of complex systems, including the theory of catastrophes, acquire a fairly clear and strict scientific and, at the same time, deep philosophical meaning.

A significant contribution to the problems of the study was the understanding that the universal ideal of "compatibility" between religion and science can be formed and gradually realized only under the condition of completeness of diversification (diversity) of discourses. It is obvious that the diversification of ideals can be completed only when their polarization reaches its limit (apogee). And such a limit is the difference between thereligious and thesecular ideal. But in order for a potentially infinite variety of discourses to turn into a global unity, it is also necessary to stabilize the interconnection of these opposites, i.e. interchangeability of religious and secular ideals. This unity of polarization and stabilization is specifically embodied in the empirical law of religious complementarity known from history (Fig. 1).

Faith in the natural person

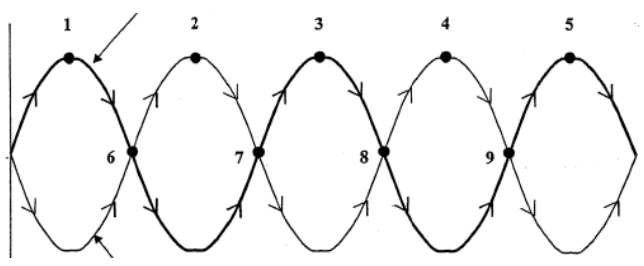

Faith in the supernatural person time

Fig. 1. Law of Religious Complementarity [18] (1, 2, 3, 4, 5 - states of spiritual crisis; 6, 7, 8, 9 states of an ideological turning point).

It is clear from this scheme that religious and scientific ideals, on the one hand, are mutually exclusive, and on the other, they presuppose each other. The growth of faith in the natural person leads to a decline in faith in the supernatural person [18]. But upon reaching a certain critical value (characterized in everyday life as a "spiritual crisis"), a turning point occurs, and then the decline in faith in the natural person (in particular, in one's own strength) naturally leads to an increase in faith in the supernatural person. But also only up to a certain state, upon reaching which the reverse process begins. Thus, the ups and downs of both scientific and religious ideals are manifested in the mutual transfer to each other of a kind of relay race of «the meaning of life».

\section{Conclusions}

The main ideological principle of the "Islamic philosophy of nature" is the idea of the interdependence of man and nature. C.-X. Nasr and other Muslim neo-traditionalists deduce him from the Islamic principle of tawhid, which affirms the unity of all that exists in an internal relation to its ontological principle - Allah. In the epistemological form, this principle is expressed in the Muslim concept of the unity of knowledge, which affirms the interconnection of all types of knowledge. Modern science approaches the same positions from a rationalistic point of view, but without a philosophical and spiritual-religious design, 
such a path does not guarantee. It is no coincidence that al-Farabi subdivided the Intellect into ten levels, the upper of which was God, and the lower one was a person striving to reach the divine level with the help of reason. "Divine", heavenly (the first Intellect) is revealed through the theology of Islam. The nature of the tenth Intellect has two sides - material, earthly and ideal, to which a person should strive. It follows from this that it is precisely philosophy, which cannot be satisfied with the analysis of the individual forms of culture science and religion, that seeks a universal synthetic vision that includes both sides. Philosophy is looking not for the unity of consequences, but for the unity of actions, not for the unity of products, but for the unity of the creative process.

Summarizing what has been said, we highlight the following research positions in the study of disasters with a religious approach:

1. The essence of religious phenomena can be understood using, first of all, critical reason.

2. Religious phenomena are directly related to the cognizing subject. Only a person who is himself a believer and has religious experience is able to comprehend the essence of religion.

3. Religion is viewed through a direct relationship to it through the mediation of critical reason. In this case, the pre-existing forms of being of religion are revised, and a conclusion is made about the inevitable appearance of "new, more modern forms."

From this logically follows the problem of renewal, reconstruction of Islamic philosophy, taking into account the emerging new challenges, namely, problems of a natural and social nature, catastrophes and crises.

\section{References}

1. Z. Milošević Islam and Science, Bulletin of the Cherepovets State University, 32-36 (2014). Access mode: https://cyberleninka.ru/article/n/islam-i-nauka-1

2. H. Alam, Fuad Globalniislam (2012). Access mode: http://alfaknjizara.rs/knjizara/politika-pravo-sociologija-ekonomija/globalni-islamhaled-fuad-alam/

3. A. Sabic-El-Rayess, Epistemological shifts in knowledge and education in Islam: A new perspective on the emergence of radicalization amongst Muslims, International Journal of Educational Development, 73, 102148 (2020). Access mode: https://doi.org/10.1016/j.ijedudev.2019.102148.https://www.sciencedirect.com/science /article/pii/S0738059319306261

4. V. Davydov, Truth about the achievements of Muslim scientists of the Golden Age. Access mode: https://gabblgob.livejournal.com/669377.html

5. M. Tarazi, The reasons for the prosperity and decline of science in the Islamic world (2013). Access mode: http://jamagat.kz/index.php/analitika/ll-prichiny-rastveta-izakatanauki-v-islamsko

6. M. Sadovic, Islam i nauka: Bog postoji i opo-minjeljude: religija i nauka, dvasaborca u borbizaopstanak $i$ razvitakcovjekanazemaljskojkugli (2012). Access mode: https://www.knjizara.com/Islam-i-nauka-Bog-postoji-i-opominje-ljude-MehmedSadovic-152652

7. A. Sabic-El-Rayess, Epistemological shifts in knowledge and education in Islam: A new perspective on the emergence of radicalization amongst Muslims, International Journal of Educational Development, 73, 102148 (2020). Access mode: https://www.sciencedirect.com/science/article/pii/S0738059319306261 
8. R. Fakhrutdin, Riza Fakhretdin: reformer, historian and politician. Access mode: https://realnoevremya.ru/articles/96898-riza-fahretdin-v-istorii-tatarskogoprosvetitelstva

9. A. Hassan, A. Suhid, N. Z. Abiddin, H. Ismail, H. Hussin, The role of Islamic philosophy of education in aspiring holistic learning, Procedia - Social and Behavioral Sciences, $\mathbf{5}$, 2113-2118 (2010). Access mode: https://www.sciencedirect.com/science/article/pii/S1877042810017970

10. A. Nawal, Al Eid, Boshra, A. Arnout, Crisis and disaster management in the light of the Islamic approach: COVID-19 pandemic crisis as a model (a qualitative study using the grounded theory), Journal of Public Affairs (2020). Access mode: https://onlinelibrary.wiley.com/doi/full/10.1002/pa.2217

11. Suyadi, Z. Nuryana,N. A. F. Fauzi, The fiqh of disaster: The mitigation of Covid-19 in the perspective of Islamic education-neuroscience, International Journal of Disaster Risk Reduction, 51, 101848 (2020). Access mode: https://www.sciencedirect.com/science/article/pii/S2212420920313509

12. S. Akter, Social cohesion and willingness to pay for cyclone risk reduction: the case for the coastal embankment improvement project in Bangladesh, Int. J. Disaster Risk Reduct, 48 (1), 1-11 (2020). Access mode: https://www.sciencedirect.com/science/article/pii/S221242091931129X

13. K. Iuchi, J. Mutter, Governing community relocation after major disasters: an analysis of three different approaches and its outcomes in Asia, Prog. Disaster Sci., 6, 100071 (2020). Access mode: https://www.sciencedirect.com/science/article/pii/S2590061720300089

14. M. Rokib, The significant role of religious group's response to natural disaster in Indonesia: the case of SantriTanggapBencana (Santana), Indones. J. Islam Muslim Soc. 2 (1), 53-77 (2012). Access mode: https://jims.iainsalatiga.ac.id/index.php/ijims/article/view/91

15. Suyadi, Z. Nuryana, N. A. F. Fauzi, The figh of disaster: The mitigation of Covid-19 in the perspective of Islamic education-neuroscience, International Journal of Disaster Risk Reduction, 51 (2020). Access mode: https://doi.org/10.1016/j.ijdrr.2020.101848

16. The Fatwa and Islamic Research Council and Muhammadiyah Disaster Management Center, Coping with Disaster: Principle Guidance from an Islamic Perspective (2016). Access mode: https://mip.umy.ac.id/wp-content/uploads/2018/07/Coping-withdisaster-principle-guidance-from-an-islamic-perspective.pdf

17. A. Chulichkov, The theory of catastrophes and the development of the world, Science and Life, 6 (2001). Access mode: https://www.nkj.ru/archive/articles/6068/

18. I. E. Sokolovskaya, Religious feeling and its influence on the level of moral consciousness of modern student youth, E3S Web of Conferences, 210, 17031 (2020). Access mode: https://doi.org/10.1051/e3sconf/202021017031 